\title{
Assessment of risks and potential of injection techniques in integrated programs to eradicate the red palm weevil: review and new perspectives
}

Michel FERRY*, Susi GoMEZ

INRA, Estación Phoenix, Apartado 996, 03201 Elche, Spain,

ferry.palm@gmail.com
${ }^{*}$ Correspondence and reprints

Received 7 May 2013

Accepted 4 September 2013

Fruits, 2014, vol. 69, p. 143-157 (C) 2014 Cirad/EDP Sciences All rights reserved

DOI: $10.1051 /$ fruits/2014005 www.fruits-journal.org

RESUMEN ESPAÑOL, p. 157
Assessment of risks and potential of injection techniques in integrated programs to eradicate the red palm weevil: review and new perspectives.

Abstract - Introduction. Plants develop mechanisms that allow them to compartmentalize injuries that they suffer during their life. In trees, pruning and injection treatments must be used in accordance with precise rules to reduce risks resulting from the injuries created. Sealing in palms. Palms, contrary to widespread belief, are quite capable of "healing" injuries (sealing); because of an anatomy quite different from trees, the sealing process in palms is much simpler. Compartmentalization of injection wounds. The controversy on the use of injection in trees is due essentially to initial mistakes that have then been rectified. Injection in palms against the red palm weevil. For palms, for decades, this technique has been employed without problems and with great efficiency against various pests, including Rhynchophorus ferrugineus, the red palm weevil (RPW). Its use has been reserved for exceptional situations either to face abnormal pest proliferation, uncontrollable by other techniques, or to implement eradication programs. Integrated eradication program. In such a program, the main aim of injection treatments is preventive. With long-persistence insecticides, the number of treatments could be greatly reduced. The resulting savings in time and money would enable the organization of the treatments of all the palms located in an infested area, and consequently the rapid eradication of the pest. New perspectives. We established that insecticides applied by injection were capable of protecting palms with only two or even one treatment per year. These results suggest a radical improvement in programs to eradicate RPW, while considerably reducing the risks to health and the environment compared with spray treatments.

Spain / Arecaceae / plant anatomy / integrated pest management / Rbynchophorus ferrugineus / invasive species / tree injection / insecticides / lesions / healing / pesticide persistence / chemoprophylaxis / pest eradication

Évaluation des risques et intérêt des techniques d'injection dans des programmes intégrés visant à éradiquer le charançon rouge du palmier: bilan et nouvelles perspectives.

Résumé - Introduction. Les plantes sont dotées de mécanismes qui leur permettent de compartimenter les blessures qu'elles subissent au cours de leur vie. Chez les arbres, l'élagage comme les traitements par injection doivent être utilisés en respectant des règles précises pour réduire les risques provoqués par les blessures créées. Scellement chez les palmiers. Contrairement à un cliché très répandu, les palmiers sont tout à fait capables de " cicatriser " leurs blessures (" scellement "). En raison d'une anatomie très différente des arbres, les processus de scellement sont beaucoup plus simples. Compartimentage de blessures d'injection. La polémique scientifique sur l'usage de l'injection chez les arbres résulte essentiellement d'erreurs initiales qui ont été ensuite corrigées. L'injection chez les palmiers contre le charançon rouge. Chez les palmiers, depuis des dizaines d'années, cette technique est utilisée sans problème et avec une grande efficacité contre divers ravageurs, dont le charançon rouge des palmiers (CRP). Son utilisation a été limitée à des situations exceptionnelles soit pour faire face à la pullulation anormale d'un ravageur, soit dans le cadre de programmes d'éradication. Programme intégré d'éradication. Dans la mise en ouvre d'un tel programme, le principal intérêt de traitements par injection est préventif. Avec des insecticides à longue persistance, le nombre des traitements pourrait être considérablement réduit. L'économie qui en résulterait en temps et argent permettrait d'organiser le traitement de tous les palmiers situés en zones infestées et, en conséquence, d'éradiquer rapidement le ravageur. Nouvelles perspectives. Nous avons établi que des insecticides appliqués par injection étaient capables de protéger les palmiers avec seulement deux ou même un seul traitement par an. Ces résultats permettent d'envisager un changement radical dans la mise en ouvre de programmes intégrés d'éradication du CRP, tout en réduisant considérablement les risques pour la santé et l'environnement en comparaison avec les traitements par pulvérisation.

Espagne / Arecaceae / anatomie végétale / gestion intégrée des ravageurs / Rbynchopborus ferrugineus / espèce envahissante / injection d'arbres / insecticide / lésion / guérison / persistance des pesticides / chimioprévention / éradication des parasites 


\section{Introduction}

The injection of various substances into trees has been implemented at least as far back as the Middle Ages [1]. Its use for plant health dates to the middle of the twentieth century and expanded in the 1970s with the apparition of the first systemic pesticides. From that period, numerous studies on the treatment of trees by injection have been realized, especially by North American researchers, who have published an abundant literature. This literature was published in parallel with several fundamental papers on the anatomical and health consequences of injuries on trees and, especially, on the description and conceptualization of "healing" mechanisms [2-16]

In fact, strictly speaking, plants do not heal. They do not regenerate injured tissues as in the animal world: the wounded cell tissues are not replaced. The cells peripheral to the injured zone react to create barriers, isolating the healthy area from the outside. For trees, this process was described by Shigo and called "compartmentalization" [17]. For palms, he used the word "sealing" [18]. It is this term that we have decided to use in this paper.

In trees, the natural mechanisms of compartmentalization occur regardless of the origin of the injury:

- boring of the tree bark by pests [19-21],

- trunk and branch breaks after storms [22],

- fires [23],

- pruning: it is especially in this domain that numerous observations have been made [24-27],

- holes drilled into the bark for sap extraction of various species; for example, in maple [28].

Similar mechanisms of compartmentalization also take place after the injection of pesticides [4, 6, 14, 29-34].

The compartmentalization of injuries prevents the introduction and progression of microorganisms and, in the case of trees, enables the reconstitution of the continuity of the secondary meristems. The absence of this natural compartmentalization capacity of wounds would constitute such a serious evolutionary disadvantage that it would not have allowed the sustainable emergence of perennial species [3, 35-38]. It is thanks to this natural capacity that pruning, often much more aggressive than injection, constitutes a current practice in arboriculture. Applied improperly, pruning and injection can lead to an injury that compartmentalizes badly, with the development of decay more or less deep within the tree [3, 39-45]. This potential risk must not be underestimated but, of course, it has not led to the abandonment or the interdiction of pruning. The potential and even the necessity of pruning evidently justify taking this risk. To eliminate or minimize it, precise standards and practices have been elaborated.

It is with the same rational approach that injection must be viewed. The use of this technique is only justified if the advantages outweigh the disadvantages. In our view, much of the controversy on the use of this technique has originated from dogmatic points of view and not from an objective assessment based on advantage/disadvantage analysis.

Contrary to widespread belief, palms "heal" or, to be more exact, seal wounds. They seal them even more safely than trees do. Palms in this paper refer to the main species affected by the red palm weevil (RPW). The absence of a cambium in palms has unfortunately led various authors to erroneously assert the impossibility of palms "healing" wounds [46-49]. This position has been listed by Shigo among the 100 myths on trees whose erroneous character he was anxious to point out [50].

An essential aspect in the compartmentalization or healing processes of an injury is the protection of the non-injured cell tissues from the outside environment, especially to prevent evaporative stress and the introduction and development of microorganisms. Palms, of course, have this capacity; otherwise, they would have probably never emerged in the vegetal world.

For palms, the model of plant compartmentalization called CODIT elaborated by Shigo and Marx is not directly applicable [4]. This model is based on the existence of 
tissues (yearly rings, medullar rays) and on the development of a callus that covers the wound. Such tissues and development do not exist in palms. The fact that the CODIT model cannot be applied to palms does not mean at all that these plants are not capable of "healing". Shigo even used the term "compartmentalize" for palms [50].

In fact, in palms, the wounded and surrounding cell tissues do react according to a process similar to that observed in trees during the first compartmentalization step: necrosis and desiccation of the wounded and neighboring cells, significant production of phenols by the parenchymatic cells and, sometimes, of suberin and tyloses, and, what is most important, sealing of the wounded zone of the vessels by gums [51-57]

In palms, there is no production of a callus: the wound will never be covered by the barrier 4 of the CODIT model. It is not because of a lack of a cambium, as explained by the authors, who affirmed that palms cannot seal injuries. The callus could be perfectly initiated from the parenchymatic cells as often occurs in trees. However, in monocotyledons, these cells generally do not produce calli $[20,57,58]$.

The main reason why palm sealing does not follow the CODIT model is the specific anatomy and development of palms compared with trees.

The activity of the terminal bud in palms is at the origin of the growth in diameter. This growth stops when the terminal bud, which is also at the origin of the growth in height, has reached a certain position in height. Consequently, the diameter of the stipe (false trunk) remains constant (it can be noted that various stresses, that influence terminal bud activities, can create some change in diameter)

In palms, there is no need for reconstitution of the injured tissue as they are not necessary for the ulterior architectural development, whereas it is indispensable for trees. Trees present an indefinite growth in diameter that is the result of the cambium activity. The development of the callus, with subsequent differentiation of the cambium (to produce xylem and phloem) and phellogen (to reconstitute the bark) in continuity with the non-wounded cambium and phellogen, is imperative because of the indefinite diameter growth in trees.

Wall 4 covering the wound is indispensable in trees, but not in palms.

These fundamental anatomical differences between palms and trees have important consequences if we compare the effects of wounds between these two groups of plants: a significant bark injury, that would often have deadly consequences in trees, is without serious consequences in palms. Furthermore, the cambium and phellogen are composed of meristematic cells that have thin walls and do not present much resistance to invasive microorganisms. Such weakness is by nature absent in palms.

Another great anatomical difference between palms and trees is the arrangement of the vascular bundles. In palms, these are distributed in the whole section of the trunk, whereas they are arranged as annual rings in trees. As Stipes indicated, the main problem of wounds in trees is that the damage caused on some rings of the sapwood (living xylem) can throw into question the survival of the tree [59]. The phloem ring presents the same fragility, or worse, because it is in a more external position. Because of the totally different distribution of the sap-conducting tissues in palms, the consequences of wounds are much less serious than in trees. It is frequent to find palms with extensive and deep injuries that not only have sealed but have not prevented the continuation of the palm growth (the bi-directional flow of sap has not been seriously compromised).

In conclusion, contrary to what is so often repeated and sometimes written in specialized books or papers on palms, palms are not only perfectly capable of sealing their wounds but are much less fragile than trees when they are injured.

\section{Controversy on the injection technique in trees}

A large part of the debate on injection is not about the possible harmful consequences 
for the health of the treated tree with this technique but about its efficacy and cost [29, 31, 60-73].

Most articles about the injuries created by injections refer to the use of this technique against Dutch elm disease (DED). This experience with elm treatment is at the origin of very surprising negative prejudices regarding injection, especially in France. These prejudices are in contradiction with the statement of many authors who underlined the efficacy of treatment by injection for preventive purposes [74-78] and even for curative ones [79, 80]. Furthermore, it was demonstrated that one of the main causes of the damage produced by injections for the control of DED is not the wound created by the injection itself but the nature of the injected pesticide solution [43] The nature of the injected products, as a significant cause of the ulterior damage produced after injection, was verified in other species [10, 40, 41].

For numerous years, the translocation properties of the fungicides used against elm graphiosis were obtained by a very elevated acidification of the injected solutions. With the advent of new pesticide formulations, which do not present this disadvantage, neither the health consequences nor the efficacy of this technique have been considered problematic; it is the cost of the treatment that limits the use of the injection technique against DED [75, 78, 80-82].

In France, it is regrettable to see that, on the basis of the past negative evaluation of results obtained against DED, injection treatments not only against DED but against all pests have been totally forbidden for numerous years. The reasons invoked for this ban are the inefficacy of the treatments and the injuries caused by the injections [83] These reasons have been no longer valid for several years, especially because injection formulations and injection methods have evolved a lot. In contrast with France, a large number of countries have authorized this technique in many cases.

Even an author who is very critical of tree injections, such as Smith, wrote: "Under special circumstances, stem injection of toxic chemicals might be a legitimate part of a tree protection program" [34]. Furthermore, in another paper that he wrote with Lewis [45], it must be underlined that his criticism of injections is based on results that were obtained with out-of-date injection techniques. These techniques presented do indeed have obvious flaws: methods based in one case on intentional separation of the bark and in another case on the use of injection pressure of between (21 and 42) $\mathrm{kg} \cdot \mathrm{cm}^{-2}$ !

\section{Unfounded polemic concerning injection for palms}

We reiterate that the palms that we are speaking about in this paper are essentially the species affected by the red palm weevil (RPW).

\subsection{Palms are not true trees}

To understand the controversy on injection, it is necessary to take into consideration an essential point well summarized by Perry et al.: "a part of the controversy and disagreements between the researchers rests on the failure to recognize the anatomical differences between the species" [1]. The differences between trees and palms are even more considerable.

We have already presented some of these differences. Among these differences, some take on great importance in relation to injection techniques.

In comparison with trees, the absence of the two rings of cambium and phellogen in palms constitutes an advantage because these fragile tissues offer less resistance to microorganism damage and are more sensitive to phytotoxicity problems. As emphasized by Shigo, dieback of the cambium after an injury can lead to the death of the tree [42]. Smith, when he raised the risk presented by some methods of injection, insisted on the importance of the cambium dieback phenomenon [34]. Haugen signaled that to reduce the phytotoxicity of injections in the cambium, it is recommended to rinse the wound with water [76]. 
In many palm species, there is no dead zone in the center of the stipe. However, in many tree species, the heart of the trunk constitutes dead wood and depends, therefore, when wounded, on passive mechanisms to resist microorganism invasion [3, 6]. The heart of the palm's stipe is not composed of dead wood but of vascular bundles and parenchymatic tissue that remain indefinitely alive and therefore are capable of employing active mechanisms to react to an injury. This important difference explains why the depth of the injection is less crucial in palms than in trees.

The presence of a cambium and of a narrow sapwood zone in trees requires more targeted injection techniques in trees than in palms.

Another risk is mentioned when trees are treated by injection: cracks or the detachment of the bark [84]. Bark in trees is quite different from the very simple palm "bark" (palm stipes are protected, in addition to the leaf bases when they are still present, by a thin barrier that plays the same role as bark in trees). In palms, there is no risk of similar damage to the bark that has been described in trees. However, too high injection pressure is not recommended for palms or trees, not for the consequences on the bark but to avoid damage to the inner cell tissues.

Palm architecture is very simple: it constitutes a stipe that keeps a constant diameter, a terminal bud and leaves all grouped around this bud. In comparison, trees have numerous branches and indeterminate diameter growth, constituting a more complex structure. In consequence, the injection of insecticide products is much simpler to achieve in palms than in trees.

Thorough distribution of the products injected into trees requires a large number of injection points [65]. Furthermore, because of the diameter growth, the number of injections changes. For trees, it is established according to the circumference and the distance between injections (one injection every $10 \mathrm{~cm}$ to $15 \mathrm{~cm}$ ), when for palms it is established according to the species.

In the end, for one tree, more than tens of injection points can be necessary when for a palm, four injection points are the

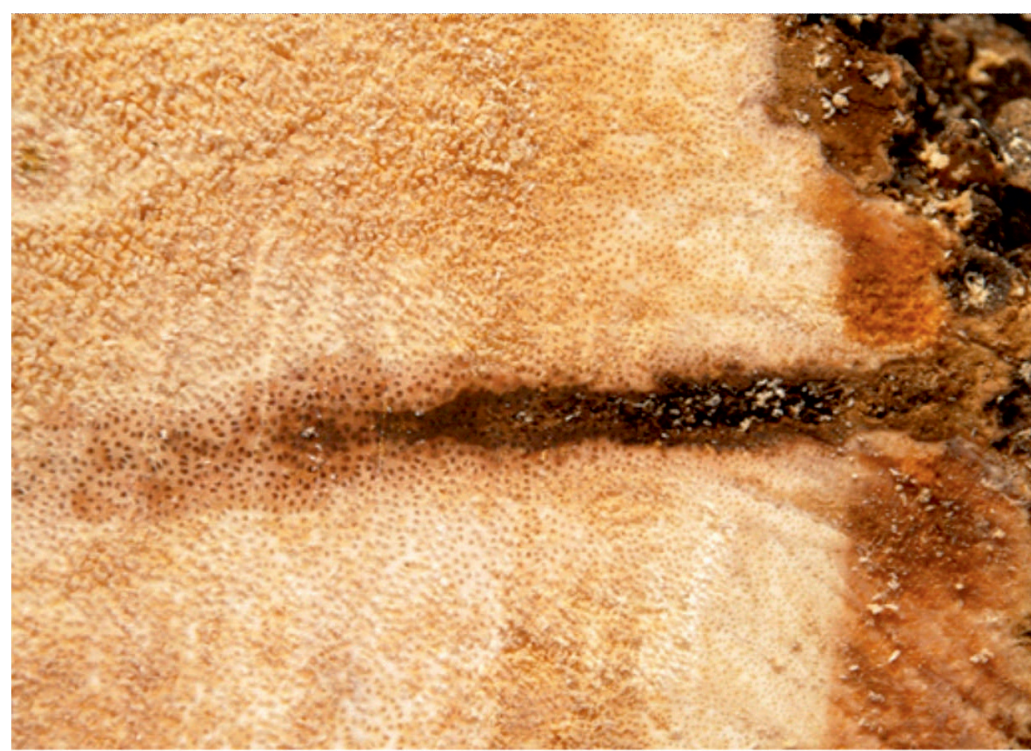

highest number corresponding to the great- Figure 1.

est diameter species. In palms, this low Sealing of a wound produced number of injection points is sufficient for by injection treatment: size of adequate distribution of the injected insecticides because the palm vascular bundles present a very particular organization: leaf vascular bundles form spirals in the stipe and are connected to the vascular bundles of the central stipe system at a great number of points [85]. Thanks to these numerous interconnections, even with a small number of injection points, the injected insecticide will be thoroughly distributed in the palm, especially in the leaves.

Such distribution is very important to control a pest such as the RPW whose preferential egg-laying sites, for palms without offshoots, are the central leaf bases [66, 67]. For palms with offshoots, like date palms, the injection must be applied as low as possible to allow the insecticide to translocate acropetally in the stipe through the xylem sap, and basipetally through the phloem sap.

After an injection treatment, the palm has a great capacity to seal the wound produced. A narrow barrier of sealing is formed. The palm perfectly isolates the wound and effectively protects the healthy cell tissues (figure 1).

The controversy created on the potential of injections to control the RPW is mainly the hole: $6 \mathrm{~mm}$ diameter, $15 \mathrm{~cm}$ depth in the stipe itself (excluding remaining leaf base). Injected insecticide: imidaclopride $20 \%$. Volume injected per hole: $2 \mathrm{~mL}$ diluted in $200 \mathrm{~mL}$ of water. Pressure: $1.5 \mathrm{~kg} \cdot \mathrm{cm}^{-2}$. Observation of the injury: 5 years after injection. 
the result of a great lack of understanding or knowledge of the fundamental differences that distinguish palms from trees. It is also the consequence of a serious ignorance of the worldwide experience acquired in use of injection treatments against several pests and diseases of various palm species. Indeed, this controversy is not supported by the opinion of the majority of the international experts of this pest [86-93].

\subsection{Injection treatments in palms}

\subsubsection{The efficacy of injection treatments in palms}

We gathered and analyzed exhaustively the existing documentation on the research and practices concerning injection in palms. The analysis of this documentation clearly demonstrates, for decades, the efficacy of this practice in a large number of cases:

- against various pests and diseases of the coconut [94-101], and of oil palms [102116],

- against the red palm weevil on date palm [85, 117-119] and on coconut [120-122]

For more than thirty years, injection treatments have been applied successfully against serious pests and diseases in oil palm and coconut plantations in Asia, Latin America and Africa, as well as against the RPW in date palm and coconut plantations.

Ginting and Desmier wrote that, since the apparition of the first systemic insecticides, at the beginning of the 1970s, the method of injection into the trunk "has been and is still used with success" against various pests difficult to control otherwise [123].

In Papua New Guinea, Dewhurst specified that "to control the insect pests of oil palm, the technique of trunk drilling and insecticide injection is the standard used by the oil palm industry and smallholder growers in PNG" [124].

Several defoliating caterpillars of the oil palm are controlled usually by injection in cases of explosive population growth [125]. According to Wood, "thousands of ha of oil palms and coconut plantations have been treated by injection" [126].
Jacquemard underlines that "injections into the stipe can be of great help" to treat small oil palm plantations against various defoliating insects and borers of oil palm [127].

In Florida, the injection technique is allowed and used to fight against Lethal Yellowing and the new LPD disease that affect several palm species.

Regarding date palm, injection techniques have been used against the RPW for twenty years in the Gulf countries and in Egypt. Against the same pest, this technique has been used in Phoenix canariensis for about ten years in the south of Spain [128].

Concerning Phoenix canariensis, the efficacy of injection was sometimes questioned. It was because the insecticide used initially was not very mobile in the stipe, accounting for the poor efficacy observed. With the newly authorized insecticides, this defect has been corrected.

In general, the main reason that sometimes has led to a premature conclusion on the ineffectiveness of this technique against the RPW is due not to the technique itself but to a basic misconception in the fight against this pest: no technique by itself, if it is not applied within an integrated eradication strategy, will be effective [129].

\subsubsection{Absence of sanitary or biomechanics problems}

Despite an exhaustive scientific and technical literature analysis, we did not find any paper that mentions sanitary or biomechanics problems caused by injection treatments in oil palm, coconut or date palm in twenty to forty years of practice. This span of time is quite sufficient to detect problems if they had occurred.

Rare are the authors who evoke the question of the "healing" of the injuries, even when the diameter of the drilled holes are large (e.g., $1.5 \mathrm{~cm}$ diameter or more). For oil palm, Mariau reports that the trauma is limited if the injection is no more than $15 \mathrm{~cm}$ in depth and if the injection hole is closed after the operation [104]. Regarding this last point, it must be mentioned that Mariau was working in very rainy regions 
and that the diameter of the injection hole was significant.

Mariau and Philippe assert that injection will not have an effect on the vigor or the production of the palms but they recommend not to practice more than four treatments in the whole palm life (for oil palm, each treatment consists of two holes per palm) [130]. The main concern that they mention is the cost. Reyes indicates that, in Colombia, if the drilled hole is not plugged, the development of rotting can be light or significant but does not exceed $2.5 \%$ of the injected palms [131].

Regarding the question of wound dressings after pruning or any other event, the accumulated experience (of about thirty years) has led the majority of arborists to consider such a practice either of no value or even harmful [8]. Our own experience on injection in Phoenix sp. demonstrates that, in normal conditions (no excessive rainy period), it is preferable not to plug the hole. In that way, rapid desiccation of the wound, the first stage of the sealing process, will be favored.

For coconut, Nadarajan and Basavanna report that the injection holes affect only a small number of vascular bundles, whereas it is well known that this palm can withstand significantly greater injury [94]. The observation of these authors is of course still more valid for Phoenix species: they have bigger stipes than coconuts.

Genty et al. confirmed the potential and the innocuousness of injection treatments while observing the injected sites. He wrote that this "method of control is from afar the most interesting by its efficiency and its innocuousness; the dissections of many injected trees (observations made 1 to 4 years after treatment) showed very homogeneous healing zones around the perforations, without any consequence for the trees. On the other hand, the experiences of injection achieved during numerous years in Asia and in Africa demonstrate the innocuousness of this method" [106].

This absence of mention of health and biomechanics problems by all the authors who wrote about injection is not at all surprising in fact, because of the great sealing capacity of palms. It is easy to observe, in parks or in date palm plantations, the extraordinary capacity of Phoenix species to seal deep and extensive injuries and, even in those cases, to maintain their mechanical stability. In comparison, the injuries produced by drilled holes for injection treatments are minimal. Of course, that does not mean that injection treatments could be realized without taking precautions. On the contrary, we consider that this technique, quite different to the usual phytosanitary plant treatments, requires that technicians and operators follow specific training on its use.

For five years now, we have trained hundreds of plant protection technicians and palm professionals in Europe and North Africa on the integrated eradication strategy of the RPW, that includes a specific component on injection technique.

\section{Conclusion and new perspectives}

\subsection{Injection technique within integrated eradication programs}

The objection that is sometimes raised against injection in palms is based on frequent serious misconceptions regarding the biology of palms as well as on insufficient knowledge of the existing literature and practices regarding the use of this technique in the world. We hope that, with this paper, we will have contributed to rectifying these two gaps.

If well applied, this technique is clearly of great potential for palm treatments against various pests and diseases, as Tomlinson himself noted in his famous book on "The structural biology of palms" [85].

Let us see now the perspectives that this technique offers in the fight against the red palm weevil (RPW).

The success of integrated programs of eradication of the RPW requires efforts and means that must be mobilized as quickly as possible after detection. The programs must 
be conceived to reach eradication of the infested areas in just a few years. Programs that are conceived to reach this objective in the medium or long term will finally cost much more and will have little chance of succeeding.

A significant part of these programs must focus on awareness, coordination and training (including especially field workers).

Another essential component must be the realization of preventive activities in each infested zone $(500 \mathrm{~m}$ to $1000 \mathrm{~m}$ around an infested palm or a trap that has captured RPW). The different preventive activities are mass trapping, early detection and quick sanitation of infested palms and preventive insecticide treatments.

The application of insecticide treatments to all the palms of an infested area is realistic only if their cost and frequency are sufficiently low and if they are easy to apply.

\subsection{New perspectives}

The preventive treatments of palms by spraying chemical or biological insecticides must be applied too frequently (every three or four weeks) to be feasible for a long period. Injection treatments with insecticides of short persistence present the same inconvenience. Furthermore, the use of the injection technique must not be considered a routine treatment that could be repeated frequently as this technique requires the drilling of holes: the hole used for one treatment cannot be reused for another one because the injury through which the product is injected will seal quickly.

Drilling a high number of injection holes will create in the long run a risk to the health of the palms or to their mechanical resistance. Increasing the diameter of the holes to eliminate the sealing barrier at each treatment will present the same inconvenience in the long term. Another technique has been experimented with to delay the sealing process by keeping the injury humid with frequent treatments. In addition to its unsustainable cost, this type of treatment will considerably increase the risk of health problems for the palm.
Therefore, this led us to implement a research program to select insecticides that can be applied by injection in an easy, safe and inexpensive way and that present a high efficacy during a long period of time.

For the assessment of the injected insecticide efficacy and persistence, we have elaborated a bio-assay method [132-134] that presents significant advantages compared with the methods usually used for such research. These methods are of three types:

- Comparison of the health state between treated and non-treated palms in field plots.

- Observation of the larval mortality by dissection of the treated palms.

- Analysis of palm leaves for insecticide residue content.

The method that we have elaborated consists of harvesting, at selected intervals of time, the target organs of the treated palms (leaves of adult palms or offshoots) and to introduce larvae into these leaves. Next, their dissection allows us to evaluate with high reliability if the insecticide is present at sufficient concentration to kill the larvae.

This method is incomparably easier to apply than the first two above-mentioned methods and is much more reliable. In relation to the third method, our method also allows one to avoid erroneous interpretations that can lead to the conclusion that an insecticide does not migrate or is no longer efficient because the chemical analysis of the active content residue is below the detection level or very low. In this way, we have established that, at least for one insecticide currently proposed in injection, it was not the initial active ingredient but its metabolite formed after injection that assured the prolonged insecticidal efficacy [134].

Our research has allowed us, on one hand, to identify two insecticides presenting a persistence of action of six months [132$134]$ to one year (in press), and on the other hand, to propose for one of them a very simple micro-injection method (in press).

Having long-persistence insecticides and simple injection methods presents a considerable potential. It permits one to simplify the field work a lot and to reduce the 
treatment cost substantially. These two parameters are absolutely indispensable to obtain RPW integrated eradication programs that are really well applied. Furthermore, the use of injection techniques has the advantage of reducing, in a significant way, environmental and human health risks in comparison with the usually applied spray treatments.

Injection treatments are an ideal option to protect ornamental palms in urban environments. In plantations of palms for fruit production, it is necessary to insure, by carefully fixing the treatment calendar and/or by choosing the right insecticide, that insecticide residue will not be present in the fruit at harvest time. The few available results have shown the absence of residues or their rapid degradation in fruits of various palms after treatment by injection or by absorption through the irrigation water [135]. However, these results have been obtained with insecticides that are no longer used or they are not very conclusive. More study is required, taking into consideration the nature of the injected insecticide, the injection method and the time of injection before harvest.

To conclude, we wish to advocate injection as a real option and component in programs of RPW eradication. These programs must integrate various complementary techniques but also involve all the actors concerned, particularly the farmers, the pruners and, more generally, all the workers that are directly and frequently in contact with the palms. Unfortunately, they are often forgotten or neglected in the implementation of these programs.

\section{References}

[1] Perry T.O., Santamour F.S., Stipes R.J., Shear T.H., Shigo A.L., Exploring alternatives to tree injection, J. Arboric. 17 (8) (1991) 217-226.

[2] Lipetz I., Wound healing in higher plants, Int. Rev. Cytol. 27 (1970) 1-28.

[3] Shigo A.L., Hillis W.E., Heartwood, discolored wood, and microorganisms in living trees, Annu. Rev. Phytopathol. 11 (1973) 197-222.
[4] Shigo A.L., Marx H.G., Compartmentalization of decay in trees, U.S. Dep. Agric., Inf. Bull. 405 (1977) 73 p.

[5] Garrett P.W., Shigo A.L., Selecting trees for their response to wounding, Metrop. Tree Improv. Alliance (Metria) Proc. 1 (1978) 6972.

[6] Shigo A.L., Shortle W.C., Compartmentalization of discolored wood in heartwood of red oak, Phytopathology 69 (1979) 710-711.

[7] Shigo A.L., Compartmentalization: a conceptual framework for understanding how trees grow and defend themselves, Annu. Rev. Phytopathol. 22 (1984) 189-214.

[8] Neely D., Tree wounds and wound closure, J. Arboric. 5 (1979) 135-140.

[9] Armstrong I.E., Shigo A.L., Funk D.T., McGinnes E.A., Smith D.E., A macroscopic and microscopic study of compartmentalization and wound closure after mechanical wounding of black walnut, Wood Fiber Sci. 13 (4) (1981) 275-291.

[10] Neely D., Tree wound closure, J. Arboric. 14 (1988) 148-152.

[11] Biggs A.R., Managing wound-associated diseases by understanding wound healing in the bark of woody plants, Arboric. 16 (1990) 108-112.

[12] Biggs A.R., Anatomical and physiological responses of bark tissues to mechanical injury, in: Blanchette R.A., Biggs A.R. (Eds.), Defense mechanisms of woody plants against fungi, Springer-Verlag, Berlin, Ger., 1992, 13-40.

[13] Schmitt U., Liese W., Wound tyloses in Robinia pseudoacacia L., IAWA J. 15 (2) (1994) 157-160.

[14] Guariguata M.R., Gilbert G.S., Interspecific variation in rates of trunk wound closure in a Panamanian lowland forest, Biotropica 28 (1) (1996) 23-29.

[15] Pearce R., Decay development and its restriction in trees, J. Arboric. 26 (2000) 111.

[16] Smith K.T., Compartmentalization today, Arboric. J. 29 (2006) 173-184.

[17] Shigo A.L., Successions of microorganisms and patterns of discoloration and decay after wounding in red oak and white oak, Phytopathology 62 (1972) 256-259.

[18] Shigo A.L., Trees anatomy, Shigo and Trees Assoc., Durham, N.H., U.S.A., 1994, 104 p. 
[19] Santamour F.S., Wound compartmentalization potential and borer damage in green ash, J. Arboric. 13 (5) (1987) 131-134.

[20] Bostock R.M., Stermer B.A., Perspectives on wound healing in resistance to pathogens, Annu. Rev. Phytopathol. 27 (1989) 343-371.

[21] Dute R.D., Miller M.E., Davis M.A., Woods F.M., McLean K.S., Effects of Ambrosia beetle attack on Cercis Canadensis, IAWA J. 23 (2) (2002) 143-160.

[22] Smith K.T., Shortle W.E., Patterns of storm injury and tree response, U.S. Dep. Agric. For. Serv., NA-TP-02-01, U.S.A., 2001.

[23] Smith K.T., Sutherland E., Fire scar formation and compartmentalization in oak, Can. J. For. Res. 29 (1999) 166-171.

[24] Neely D., Closure of branch pruning wounds with conventional and 'Shigo' cuts, J. Arboricult. 14 (1988) 261-264.

[25] Eisner N.J., Gilman E.F., Grabosky J.C. Branch morphology impacts compartmentalization of pruning wounds, Arboric. Urban For. 28 (2) (2002) 99-105.

[26] O'Hara K., Pruning wounds and occlusion: A long-standing conundrum in forestry, J. For. 105 (2007) 131-138.

[27] Clark L.R., Matheny N., What does research tell us about the practice of pruning in arboriculture, Arboric. News (2010) 41-44.

[28] Morselli M.F., Effects of the use of para formaldehyde (PFA) sterilising pellets on sugar maple health: A review, in: XXth World Cong., IUFRO, Tampere, Finland, 1995.

[29] Dutcher J.D., Worley R.E., Littrell R.H., Trunk injection of dicrotophos and trunk implantation of acephate to control foliar pecan pests, J. Arboric. 6 (1980) 294-297.

[30] Dujesiefken D., Rhaesa A., Eckstein D. Stobbe H., Tree wound reactions of differently treated boreholes, J. Arboric. 25 (1999) 113-123.

[31] Ferracini C., Alma A., How to preserve horse chestnut trees from Cameraria ohridella in the urban environment, Crop Prot. 27 (9) (2000) 1251-1255.

[32] Doccola J., Wild P., Bristol E., Lojko J., Differential wound response for deciduous hardwood trees using arboplug technology, Arbojet, Winchester, M.A., U.S.A., 2004 $22 \mathrm{p}$.

[33] Dujesiefken D., Liese W., Shortle W., Minocha R., Response of beech and oak to wounds, Eur. J. For. Res. 124 (2005) 113117.

[34] Smith K.T., Tree biology and problem trees, Arboric. News 14 (2) (2005) 24-26.

[35] Shigo A.L., How trees survive after injury and infection, in: Wilson C.L., Scorza R. (Eds.), Proc. stone fruit tree decline workshop, Appalachian fruit research station, Kearneysville, W.V., U.S.A., 1985, 133-138..

[36] Bonsen K.J., Kucera L.J., Vessel occlusions in plants: morphological, functional and evolutionary aspects, IAWA Bull. 11 (1990) 393399.

[37] Romero C., Bolker B.M., Effects of stem anatomical and structural traits on responses to stem damage: an experimental study in the Bolivian Amazon, Can. J. For. Res. 38 (2008) 611-618.

[38] Romero C., Bolker B.M., Edwards C.E., Stem responses to damage: the evolutionary ecology of Quercus species in contrasting fire regimes, New Phytol. 182 (1) (2009) 261271.

[39] Shigo A.L., Successions of organisms in discoloration and decay of wood, For. Res. 2 (1967) 237-299.

[40] Shigo A.L., Campana R., Discolored and decayed wood associated with injection wounds in American elm, J. Arboric. 3 (1977) 230-235.

[41] Costonis A.C., The wounding effects of Mauget and creative sales injections, J. Arboric. 6 (1980) 204-208.

[42] Shigo A.L., Targets for proper tree care, J. Arboric. 9 (11) (1983) 285-294.

[43] Andersen J.L., Campana R.J., Shigo A.L., Shortle W.C., Wound response of Ulmus americana, 1: Results of chemical injection in attempts to control Dutch elm disease, J. Arboric. 11 (5) (1985) 137-142.

[44] Smith K.T., Wounding, compartmentalization, and treatment tradeoffs, J. Arboric. 14 (1988) 226-229.

[45] Smith K.T., Lewis P.A., Potential concerns for tree wound response from stem injection, in: Onken B., Reardon R. (Compil.), Proc. Third Hemlock Wooly Adelgid Conf., Asheville, NC, Feb. 1-3, 2005, USDA For. Serv. Publ., U.S.A., 2005.

[46] Deleuze J., Palmiers pour le climat méditerranéen, Ed. Champlour, Marly-le-Roi, France, 1995, $144 \mathrm{p}$.

[47] Howard F.W., Moore D., Giblin-Davis R.M., Abad R.G., Insect pests of palms and their 
control, CAB Int., Oxon, N.Y., U.K., 2001, $400 \mathrm{p}$.

[48] Del Cañizo J.A., Palmeras, Ed. MundiPrensa, Madrid, España, 2002, 704 p.

[49] Moya B., Plumed J., Littardi C., La poda de las palmeras ornamentales, AEA, Valencia, España, 2005, 266 p.

[50] Shigo A.L., 100 tree myths, Shigo and Trees Assoc., Durham, N.H., U.S.A., 1993, 80 p.

[51] Bloch R., Wound healing and necrosis in air roots of Phoenix Reclinata and leaves of Araucaria imbricata, Am. J. Bot. 24 (1937) 279-287.

[52] Fisher J.B., Control of growth and development in the monocotyledons - new areas of experimental research (A), Q. Rev. Biol. 48 (2) (1973) 291-298.

[53] Shigo A.L., Trees anatomy, Shigo and Trees Assoc., urham, N.H., U.S.A., 1993, 104 p.

[54] Weiner G., Liese W., Wound response in the stem of the Royal palm, IAWA J. 16 (4) (1995) 433-442.

[55] Ball L., Palms not just for the tropics, Arboric. News (2005) 13-16.

[56] Broschat T.K., Elliott M.L., Normal abnormalities in palm, Univ. Fla. Ext. Serv., Gainesville, U.S.A., 2007, 7 p.

[57] Aloni R., Plotkin T., Wound induced and naturally occurring regenerative differentiation of xylem in Zea mays, Planta 163 (1985) 126132.

[58] Rittinger P., Biggs A., Peirson D., Histochemistry of lignin and suberin deposition in boundary layers formed after wounding in various plant species and organs, Can. J. Bot. 65 (1987) 1886-1892.

[59] Stipes R.J., Glitches and gaps in the science and technology of tree injection, J. Arboric. 14 (1988) 165-172.

[60] Sanchez-Zamora M.A., Fernandez-Escobar R., Injector-size and the time of application affects uptake of tree trunk-injected solutions, Sci. Hortic. 84 (1-2) (2000) 163-177.

[61] Sanchez-Zamora M.A., Fernandez-Escobar R., Uptake and distribution of trunk injections in conifers, J. Arboric. 30 (2) (2004) 73-79.

[62] Cowles R.S., Cheah C.S., Montgomery M.E., Comparing systemic imidacloprid application methods for controlling hemlock woolly adelgid, in: Onken B., Reardon R. (Compil.), Third Symp. Hemlock Woolly Adelgid in the Eastern United States, Asheville, NC,
Feb. 1-3, 2005, Forest Health Technology Enterprise Team, Morgantown, W.V., U.S.A., 2005, 169-172.

[63] Harrell M., Imidacloprid concentrations in green ash (Fraxinus pennsylvanica) following treatments with two trunk-injection methods, Arboric. Urban For. 32 (3) (2006) 126129.

[64] Poland T.M., Haack R.A., Petrice T.R, Miller D.L., Bauer L.S., Gao R., Field evaluations of systemic insecticides for control of Anoplophora glabripennis (Coleoptera: Cerambycidae) in China, J. Econ. Entomol. 99 (2) (2006) 383-392.

[65] Doccola J.J., Bristol E.J., Sifieet S.D., Lojko L., Wild P.M., Efficacy of trunk-injected imidacloprid in the management of hemlock woolly adelgid (Adelges tsugae), Arboric. Urban For. 33 (1) (2007) 12-21.

[66] Ferry M., Gómez S., Une nouvelle stratégie contre le charançon rouge des palmiers, Phytoma 620 (2008) 24-28.

[67] Ferry M., Gómez S., Charançon rouge des palmiers, mises au point sur la lutte, Phytoma 658 (2012) 38-41.

[68] Xu T., Jacobsen C.M., Hara A.H, Lia Ji, Lie Q.X., Efficacy of systemic insecticides on the gall wasp Quadrastichus erythrinae in wiliwili trees (Erythrina spp.), Pest Manag. Sci. 2009 (65) (2008) 163-169.

[69] Cowles R.S., Lagalante A.F., Activity and persistence of systemic insecticides for managing hemlock woolly adelgids, in: 20th USDA Interagency Research Forum on Gypsy Moth and Other Invasive Species, Annapolis, MD, U.S.A., 2009.

[70] Doccola J.J., Smith S.L., Strom R.L., Medeiros A.C., Von Allmen E., Systemically applied insecticides for treatment of erythrina gall wasp, Quadrastichus erythrinae Kim, Arbor. Urban For. 35 (4) (2009) 173-181.

[71] Herms D.A., McCullough D.G., Smitley D.R, Sadof C.S., Williamson R.C., Nixon P.L., Insecticide options for protecting ash trees from emerald ash borer, North Central IPM Center bulletin (2009) $12 \mathrm{p}$.

[72] Mota-Sanchez D., Cregg B.M., McCullough D.G., Poland T.M., Hollingworth R.M., Distribution of trunk-injected 14C-imidacloprid in ash trees and effects on emerald ash borer (Coleoptera: Buprestidae) adults, Crop Prot. 28 (2009) 655-661.

[73] Diling C., Lambdin P., Grant J., Rhea R., Spatial and temporal distribution of imidacloprid in Eastern Hemlock in the Southern 
Appalachians, J. Econ. Entomol. 103 (2) (2010) 368-373.

[74] Pinon J., Aux ormes citoyens, Courr. Cell. Environ. 8 (1989).

[75] Pinon J., Feugey L., La graphiose de l'orme: une maladie dévastatrice aux causes bien identifiées, Rev. For. Fr. XLVI - 5 (1994) 422430.

[76] Haugen L., How to identify and manage Dutch elm disease, USDA, NA-PR-07-98, 1998.

[77] Paulsrud B., Fungicide injections will they prevent Dutch elm disease? Home Yard Garden Pest Newsl. 26 (2000) 5-6.

[78] Faccoli M., Elm bark beetles and Dutch elm disease: tests of combined control, J. Pest Sci. 74 (2001) 22-29.

[79] Lanier G., Therapy for Dutch elm disease, J. Arboric. 149 (1988)

[80] Haugen L., Stennes M., Fungicide injection to control Dutch elm disease understanding the options, Plant Diagn. Q. 20 (2) (1998) 2938.

[81] Pinon J., Husson C., Au chevet de la forêt, SCEREN - CNDP, TDC $n^{\circ}$ 890, 2005, 56 p.

[82] Kondo E.S., Scope and limitations of carbendazim- $\mathrm{H}_{2} \mathrm{PO}_{4}$ injections in Dutch elm disease control, J. Arboric. 4 (1978) 80-86.

[83] Anon., Rapport annuel qualité et de la protection des végétaux, Année 2005, FREDON Paca, Hyères, France, 2006.

[84] Murdoch C.W., Coleman J.S., Campana R.J., Bark cracks associated with injection wounds in elms, J. Arboric. 9 (3) (1983).

[85] Tomlinson P.B., The structural biology of palms, Clarendon Press, Oxford, U.K., 1990.

[86] Abraham V.A., Al-Shuaibi M.A., Faleiro J.R., Abuzuhairah R.A., Vidyasagar P.S., An integrated management approach for red date palm weevil, Rhynchophorus ferrugineus Oliv., a key pest of date palm in Middle East, Sultan Qabus Univ. J. Sci. Res. Agric. Sci. 3 (1998) 77-84.

[87] El-Ezaby F.A., Injection as a method to control the red Indian date palm weevil Rhynchophorus ferrugineus, Arab. J. Plant Prot. 15 (1) (1997) 31-38.

[88] Abraham V.A., Faleiro J.R., Nair C.P.R, Nair S.S., Present management technologies for red palm weevil Rhynchophorus ferrugineus Olivier (Coleoptera: Cuculionidae) in palms and future thrust areas, Pest Manag. Hortic. Ecosyst. 8 (2) (2002) 69-81.
[89] Soroker V., Blumberg D., Haberman A.M., Hamburger-Rishard M., Reneh S., Talebaev S., Anshelevich L., Harari A.R., The current status of red palm weevil infestation in date palm plantations in Israel, Phytoparasitica 33 (2005) 97-106.

[90] Barranco P., Lorente F., Alcázar M.D., Peña J., Control de Rhynchophorus ferrugineus en España: ensayos y aplicaciones en campo. I jornadas internacionales sobre el picudo rojo de las palmeras, Fund. Agrimed, Valencia, Espana, 2006, pp. 105-117.

[91] Faleiro J.R., A review on the issues and management of red palm weevil Rhynchophorus ferrugineus (Coleoptera: Rhynchophoridae) in coconut and date palm during the last one hundred years, Int. J. Trop. Insect Sci. 26 (3) (2006) 135-154

[92] Ferry M., Gómez S., Une nouvelle stratégie contre le charançon rouge des palmiers, Phytoma 620 (2008) 24-28.

[93] Gómez S., Ferry M., Barbado J., Hernandez F., Montero F., Aplicación de una estrategia de control integrado del picudo rojo de las palmeras (Rhynchophorus ferrugineus), Phytoma 206 (2009) 29-36.

[94] Nadarajan L., Channa Basavanna G.P., Trunk injection of systemic insecticides against the coconut black headed caterpillar Nephantis serinopa Meyrick (Lepidoptera: Cryptophasidae), Oléagineux 36 (1981) 239-245.

[95] Franqueville H., Renard J.L., Intérêt du phosethyl-Al dans la lutte contre le Phytophtora du cocotier. Modalité d'application, Oléagineux 44 (7) (1989) 351-358.

[96] Kanagaratnam P., Pinto J.L., Effect of monocrotophos on the leaf eating caterpillar, Opisina arenosella Walk., when injected into the trunk of the coconut Palm, Cocos 3 (1985) 09-15.

[97] Thevenin J.M., Motulo H.F.J., Kharie S., Renard J.L., Chemical control of coconut bud rot caused by Phytophthora in Indonesia, Plant. Rech. Dév. 2 (6) (1995) 41-50.

[98] Fernando L.C.P., Wickramananda J.R., Aratchige N.S., Status of coconut mite, Aceria guerreronis in Sri Lanka, In: Proc. International Workshop on Coconut mite (Aceria guerreronis), 6-8 January 2000, Coconut Res. Inst., Sri Lanka, 2002, 1-12.

[99] Jayalakshmi V., Khan H.H., Ganoderma disease of coconut, Indian Coconut J. March (2003) 10-15.

[100] Anon., Developing Asia-pacific strategy for forest invasive species: the coconut beetle 
problem-bridging agriculture and forestry, Rep. Asia-Pacific For. Invas. Spec. Netw. Workshop, 22-25 Feb., Ho Chi Minh City, Vietnam, 2005.

[101] Fu Y., Yanlrun X., Occurence and control of coconut leaf beetle in china, in: Rep. expert consultation on coconut beetle outbreak in APPC member countries, 26-27 Oct. 2004, Bangkok, FAO-RAP publ., Bangkok, Thailand, 2004, 35-81.

[102] Wood B.J., Trunk injection of systemic insecticides against the bagworm, Metisa plana (Lepidoptera: Pyralidae) on oil palm, Oléagineux 29 (11) (1974) 499-505.

[103] Hutauruk C., Sipayung A., Development of trunk injection of systemic insecticides against Setora nitens and Thosea asigna on oil palm in North Sumatra, In: Proc. Plant Prot. Conf., Kuala Lumpur, Mal., 1978, 265278.

[104] Mariau D., Method of controlling Coelaenomenodera (Coleoptera Hispidae) by injecting systemic insecticides into the trunk of the oil palm, Oléagineux 34 (2) (1979) 51-58.

[105] Vessey J.C., Control of a leaf spot on oil palm in Honduras with insecticides, Oléagineux 36 (5) (1981) 229-232.

[106] Genty P., Garzon M., Garcia R., Damage and control of the Leptopharsa-Pestalotiopsis complex in oil palm, Oléagineux 38 (5) (1983) 291-299.

[107] Reyes A., Añublo foliar de la palma africana en Colombia, importancia económica, etiología y control, in: VI semin. Problemas fitopatologicos de la palma africana, Bucaramanga, Colombia, 1988.

[108] Singh G., Management of oil palm pests and diseases in Malaysia in 2000, in: Kadir A.A.S.A., Barlow H.S. (Eds.), Pest management and the environment in 2000, CABI Int., Wallingford, U.K., 1992, 195-212.

[109] Caudwell R.W., Orrell I., Integrated pest management for oil palm in Papua New Guinea, Integr. Pest Manag. Rev. 2 (1) (1997) 17-24.

[110] Young G.R., A review of Sexava research and control methods in Papua New Guinea, in: Proc. Sixth workshop for tropical agricultural entomologists, Darwin, Austr., 1998, 31-44.

[111] Caudwell R.W., The successful development and implementation of an integrated pest management system for oil palm in
Papua New Guinea, Integr. Pest Manag. Rev. 5 (4) (2000) 297-301.

[112] Hean Y.T., The intelligent management of Lepidoptera leaf eaters in mature oil palm by trunk injection (a review of principles), Planter 76 (887) (2000) 99-107.

[113] Wood B.J., Pest control in Malaysia's perennial crops: A half century perspective tracking the pathway to integrated pest management, Integr. Pest Manag. Rev. 7 (2002) 173-190.

[114] Jelani A.R., Hitam A., Khalid R., Serna L.A., Shuib A.R., Rashid A., Ismael F., Mechanical trunk injection for control of Ganoderma, MPOB Inf. Ser. 215 (2004) 4 p.

[115] Page W.W., Lord S., The oil palm industry's approach to the use of pesticides in Papua New Guinea, Planter 82 (958) (2006) 13-21.

[116] Anon., Trunk injection oil palms. A virtue born of necessity, Courrier Agrochem (2009) 2021.

[117] Abdallah F.F., Al-Khatri S.A., Research higlights - The effectiveness of trunk injection and fumigation for the control of the red palm weevil, Rhynchophorus ferrugineus Oliver, in date palm, Arab Near East Plant Prot. Newsl. 29 (1999) 17-21.

[118] Abdallah F.F., Al-Khatri S.A., The effectiveness of trunk injection and fumigation for the control of the red palm weevil, Rhynchophorus ferrugineus Oliver, in date palm, J. Plant Prot. Trop. 13 (1) (2000) 17-21.

[119] Azam K.M., Razv S.A., Control of the red palm weevil, Rhynchophorus ferrugineus Olivier, using prophylactic spraying of date palms and trunk injection, in: 2nd Int. Conf. Date Palms, U.A.E. Press, Al-Ain, U.A.E., 2001, 216-222.

[120] Lakshmanan P.L., Subba Rao P.B., Subramanian T.R., A note on the control of the coconut red palm weevil Rhynchophorus ferrugineus with certain new chemicals, Madras Agric. J. 59 (11/12) (1972) 638-639.

[121] Muthuraman M., Trunk injection of undiluted insecticides - a method to control coconut red palm weevil, Rhynchophorus ferrugineus Fab., Indian Coconut J. 15 (1984) 12-14.

[122] Jose F., Arivudainambi S., Gailce L., Management of red palm weevil, Rhyncophorus ferrugineus (Curculionidae: Coleoptera), Plant Arch. 8 (2) (2008) 705-707.

[123] Ginting C.U., Desmier R., Utilisation de la technique d'absorption racinaire d'insecticides systémiques pour une protection à 
long terme des cocotiers et autres cultures industrielles, Oléagineux 42 (2) (1987) 63-71.

[124] Dewhurst C., Trunk drilling, OPRAtive Word Techn. Note 9, PNGOPRA, Kimbe, PNG, 2006, 3 p.

[125] Janick J., Paull R.E., The encyclopedia of fruit \& nuts, CABI Publ.,Wallingford, U.K., 2008.

[126] Wood B.J., Book review insects on palms, Crop Prot. 21 (2002) 597-598.

[127] Jacquemard J.C., Le palmier à huile, Ed. Maisonneuve et Larose, Paris, Fr., 1995.

[128] Hernandez-Marante D., Folk F., Sanchez A., Fernandez-Escobar R., Control del curculiónido ferruginoso de las palmeras (Rhynchophorus ferrugineus Olivier) mediante inyecciones al tronco y pulverización foliar, Bol. San. Veg. Plagas 29 (4) (2003) 563-574.

[129] Ferry M., Gomez S., El picudo rojo de la palmera datilera: gravedad de la plaga en España y necesidad de un cambio radical y urgente de estrategia en la lucha, Phytoma 185 (2006) 42-46.

[130] Mariau D., Philippe R., Advantages and disadvantages of methods of chemical control of Coelaenomenodera minuta (Coleoptera Chrysomelidae) an oil palm-mining insect of the Hispidae family, Oléagineux 38 (6) (1983) 365-367.
[131] Reyes Rincon A., A practical and economical way of plugging up holes in oil palm stems after treatment by injection, Oléagineux 43 (1) (1988) 9-12.

[132] Estevez A., Ferry M., Gomez S., Endotherapy in palms. Study of the efficiency and persistency of thiametoxam in preventive treatments against the red palm weevil, Phytoma 226 (2011) 42-48.

[133] Gómez S., Estevez A., Olmos M., Ferry M., Development of a new method to evaluate efficiency and persistency of active substances used by endotherapy in adult palms for the control of Rhynchophorus ferrugineus Olivier, in: VII Ntl. Congr. Appl. Entomol., Abstracts Proc., SEEA, Madrid, Spain, 2011, 40.

[134] Gómez S., Estevez A., Ferry M., Endotherapy in palms. Study of the efficacy and persistence of thiametoxam in preventive treatments against the red palm weevil, in: ESA Annu. Meet., ESA, Reno, U.S.A., 2011.

[135] Khan A.I., Azam K.M., Razvi S.A., Pesticides residual analysis of date palm fruits by gaz-chromatography mass-spectrophotometry, in: Proc. 2nd Int. Conf. Date Palms, U.A.E. Press, Al-Ain, U.A.E., 2001, 211215. 
Evaluación de riesgos y técnicas de inyección de interés en los programas integrados para erradicar el picudo rojo de las palmeras: logros y perspectivas nuevas.

Resumen - Introducción. Las plantas están dotadas de mecanismos que les permiten compartimentar las heridas que sufren a lo largo de su vida. En árboles, tanto la poda como los tratamientos por inyección deben utilizarse respetando reglas precisas para reducir los riesgos provocados por las heridas creadas. Sellado en palmeras. Contrariamente a un cliché muy expandido, las palmeras son completamente capaces de "cicatrizar" sus heridas ("sellado"). Por su anatomía muy diferente a la de los árboles, los procesos de sellado son mucho más simples. Compartimentación de heridas de inyección. La polémica científica sobre el uso de la inyección en los árboles resulta esencialmente de errores iniciales que han sido posteriormente corregidos. Inyección en palmeras contra el picudo rojo. En palmeras, esta técnica se utiliza sin problema y con una gran eficacia desde hace decenas de años contra diferentes plagas, entre ellas el picudo rojo de las palmeras (PRP). Su utilización se ha limitado a situaciones excepcionales, bien para enfrentar una población anormalmente elevada de una plaga o bien en el marco de un programa de erradicación. Programa integrado de erradicación. En la puesta en marcha de tal programa, el principal interés de los tratamientos por inyección es preventivo. Utilizando insecticidas de larga persistencia, el número de tratamientos se podría reducir considerablemente. El ahorro que resultaría en tiempo y en dinero permitiría organizar el tratamiento de todas las palmeras situadas en zonas infestadas y, consecuentemente, erradicar rápidamente la plaga. Nuevas perspectivas. Hemos establecido que insecticidas aplicados por inyección eran capaces de proteger las palmeras con únicamente dos o incluso con un solo tratamiento por año. Estos resultados permiten imaginar un cambio radical en la puesta a punto de programas integrados de erradicación del PRP, reduciendo considerablemente los riesgos para la salud y el medioambiente en comparación con los tratamientos por pulverización.

España / Arecaceae / anatomía de la planta / gestión de lucha integrada / Rbynchophorus ferrugineus / especie invasiva / inyección en el árbol / insecticidas / lesiones / curación / persistencia de los plaguicidas / profilaxis química / erradicación de plagas 